\title{
喉頭・気管に浸潤した甲状腺癌症例の検討
}

\author{
*桜井 一生, 岩田 重信, 高須 昭彦 \\ 森茂樹, 西山 禮二, 横井 昌哉
}

\section{A Clinical Study on Thyroid Carcinoma Invading into the Larynx and the Trachea}

\author{
Kazuo Sakurai, M.D., Shigenobu Iwata, M.D., \\ Akihiko Takasu, M.D., Shigeki Mori, M.D., \\ Reiji Nishiyama, M.D. and Masaya Yokoi, M.D. \\ Department of Otolaryngology, Fujita-Gakuen Health \\ University School of Medicine, Toyoake
}

\begin{abstract}
The authors encountered 12 cases of thyroid carcinoma invading into the larynx and the trachea in clinic. They were one male and 11 females, and their age was ranged from 48 to 75 years. Histopathological examination revealed papillary carcinoma in 8 cases, follicular carcinoma in one case, anaplastic carcinoma in 2 cases and squamous cell carcinoma in one case. CT scan of the neck and tomography of the larynx and neck were extremely useful to evaluate an extension of the tumor invasion in preoperative examinations. Their prognosis was that 8 patients were alive, 2 patients were died from local tumor recurrence, and the other 2 patients were died from lung metastasis.
\end{abstract}

Key words : 甲状腺癌, 喉頭・気管浸潤

\section{I 、はじめに}

甲状腺癌は，一般に発育が緩慢で臨床的悪性 度は低いとされている。しかし，われわれ耳鼻 咽喉科医が取り扱う甲状腺癌症例は, 一般的に いって嗄声や呼吸困難を主訴とする進行癌症例 が多(1)223)4)。われわれは, 過去 9 年間に喉頭・ 気管に浸潤した甲状腺癌 12 例を経験し，これら の症例に対して積極的に手術を施行し良好な結 果を得たので臨床像につき報告する。

\section{II. 対象症例}

症例は表 1 に示すごとく，昭和 52 年より昭和 60 年までの 9 年間に当科にて診断治療した甲状 腺癌症例 48 例のうち，喉頭・気管に腫瘍の浸潤 を認めた12例（25\%）である。

*藤田学園保健衛生大学医学部耳鼻咽喉科
病理組織像は, 乳頭癌 8 例, 濾胞癌 1 例, 未 分化癌 2 例，扁平上皮癌 1 例であった。未分化 癌の 1 例と扁平上皮癌の 1 例は, 乳頭癌との混 在例であった。

自覚症状は, 嗄声 6 例, 呼吸困難 5 例と腫瘍 の周囲組織への浸潤，圧迫による症状を訴えた 症例が多かったが，腫瘍が喉頭・気管内へ浸潤 しているにもかかわらず，頸部腫瘤や前頸部違 和感のみを主訴とした症例も 3 例あった。

病悩期間は，最短 14 日から最長 10 年であった が，症状出現より 1 年以上経過してから受診し たものが 3 例みとめられた。他は，6 月月以内 に受診していた。

初診時，反回神経麻痺を認めたものは，12例 中 7 例 $(58 \%)$ であった。嗄声を訴えた 6 例中 5 例に，また呼吸困難をきたした 5 例中 4 例に 反回神経麻痺を認めた。 
表 1 喉頭・気管に浸潤した甲状腺癌症例

\begin{tabular}{|c|c|c|c|c|c|c|c|c|c|c|}
\hline \multirow{2}{*}{$\begin{array}{l}\text { 症 } \\
\text { 例 }\end{array}$} & \multirow{2}{*}{ 性 } & \multirow{2}{*}{$\begin{array}{l}\text { 年 } \\
\text { 齢 }\end{array}$} & \multirow{2}{*}{ 病理組織 } & \multirow{2}{*}{ 自覚症状 } & \multirow{2}{*}{$\begin{array}{ll}\text { 病 悩 } \\
\text { 期 間 }\end{array}$} & \multirow{2}{*}{$\begin{array}{l}\text { 反回神 } \\
\text { 経麻㽻 }\end{array}$} & \multirow{2}{*}{\begin{tabular}{|l} 
頸部リン \\
ハハ節転移
\end{tabular}} & \multicolumn{2}{|c|}{ 手 術 術 式 } & \multirow{2}{*}{ 転帰 } \\
\hline & & & & & & & & 甲状腺 & 喉頭・気管 & \\
\hline 1 & $\mathrm{~F}$ & 53 & 乳頭癌 & $\begin{array}{l}\text { 嗄声 } \\
\text { 呼困難 }\end{array}$ & 3 年 & $(+)$ & $(+)$ & 全摘 & 喉頭全摘 & 6年5力月生存 \\
\hline 2 & $\mathrm{~F}$ & 57 & 乳頭癌 & 嗄声 & 6 力月 & $(+)$ & $(+)$ & 全摘 & 喉頭全摘 & 5 年 10 力月生存 \\
\hline 3 & $\mathrm{~F}$ & 70 & 乳頭癌 & \begin{tabular}{|l} 
嗄声 \\
吸困難
\end{tabular} & 3 年 & $(+)$ & $(+)$ & 全摘 & 喉頭全摘 & 3年死亡 \\
\hline 4 & $\mathrm{~F}$ & 50 & 乳頭癌 & 頸部腫瘤 & 3 力月 & $(-)$ & $(+)$ & 全摘 & 喉頭全摘 & 月生存 \\
\hline 5 & $\mathrm{~F}$ & 75 & 乳頭癌 & 頸部腫瘤 & 14日 & $(-)$ & $(+)$ & 全摘 & 気管開空 & 5 年7 カ月死亡 \\
\hline 6 & $\mathrm{~F}$ & 63 & 滤胞癌 & 嗄声 & 4 力月 & $(+)$ & $(-)$ & 全摘 & 気管開空 & 7年生存 \\
\hline 7 & $\mathrm{~F}$ & 59 & 乳頭癌 & 嗄声 & 2 力月 & $(+)$ & $(+)$ & 全摘 & 気管開空 & 6年生存 \\
\hline 8 & $\mathrm{~F}$ & 56 & 未分化癌 & $\begin{array}{l}\text { 嗄声 } \\
\text { 呼困難 }\end{array}$ & 4 力月 & $(-)$ & $(+)$ & 全摘 & 気管開空 & 2力月死亡 \\
\hline 9 & $\mathrm{~F}$ & 62 & 未分化癌 & $\begin{array}{l}\text { 頸部腫瘤 } \\
\text { 難 }\end{array}$ & 10年 & $(+)$ & $(-)$ & 全摘 & 気管開空 & 5 年生存 \\
\hline 10 & $\mathrm{~F}$ & 48 & 乳頭癌 & 前頸部違和感 & 3 力月 & $(-)$ & $(+)$ & 亜全摘 & 気管開空 & 2 年10力月生存 \\
\hline 11 & $\mathrm{M}$ & 68 & 扁平上皮癌 & $\begin{array}{l}\text { 咳濑 } \\
\text { 呼困難 }\end{array}$ & 5 力月 & $(+)$ & $(-)$ & 手術不能 & 手術不能 & 10 力月死亡 \\
\hline 12 & $\mathrm{~F}$ & 53 & 乳頭癌 & 頸部腫瘤 & 1 力月 & $(-)$ & $(-)$ & 垔全摘 & 気管開空 & 2 年3力月生存 \\
\hline
\end{tabular}

病理組織学的に頸部リンパ節転移を認めたも のは，12例中 8 例 $(67 \%)$ であった。

手術術式は, 甲状腺に対しては, 手術不能で あった 1 例を除くと 9 例に全摘術を，2例に亜 全摘術を施行した。頸部リンパ節に対しては, 全例に両側の modified neck dissection を行な った。喉頭・気管に対しては, 喉頭全摘を 4 例 に，気管開空を 7 例に行なった。気管開空術の 範囲は, 腫瘍の浸潤範囲に応じて行なっている が，輪状軟骨より上方へ腫瘍が浸潤している場 合は喉頭全摘術の適応と考えている。気管開空 術後の形成には, 局所の有茎皮弁を 4 例に, DP 皮弁を 2 例に用いた。

転帰は, 12 例中 8 例は生存し, 4 例が死亡し たが, 症例 (3) は術後 3 年, 症例 (8) は術後 2 力 月で肺転移をきたし死亡した。また手術不能で あった症例 (11) は, 放射線治療, 化学療法を施 行したが，腫瘍のコントロールができず10カ月 後に死亡した。症例 (5) は, 5 年 7 カ月後に頸部 リンパ節再発をきたし死亡した。このうち, 症 例 (8) は末分化癌, 症例 (11) は扁平上皮癌であっ た。

\section{III. 考 察}

甲状腺癌は, 一般に女性に多く発症し, 発症 年齢も若く, 30 歳代, 40歳代にも好発する。こ
れに対し，喉頭・気管に浸潤した進行例では男 性の比率が高くなり, 平均年齢も高くなる ${ }^{5)}$ 。当 科で治療した甲状腺癌症例48例中，喉頭・気管 に浸潤を認めない36例の平均年齢は50歳である のに対し，喉頭・気管浸潤をきたした 12 例では 59歳と高齢者に多い傾向であった。

病理組織型では, 乳頭癌 8 例, 濾胞癌 1 例, 未分化癌 2 例, 扁平上皮癌 1 例であった。津森 $ら^{6)}$ は, 気道浸潤例14例を検討し, 組織学的には 乳頭癌 10 例, 濾胞癌 1 例, 未分化癌 2 例, 扁平 上皮癌 1 例であったと報告している。未分化癌 や扁平上皮癌は, 局所浸潤が強く臨床的悪性度 はきわめて高い。したがって, 喉頭・気管へ浸 潤した甲状腺癌症例では, 未分化癌や扁平上皮 癌の頻度が高くなるものと思われた。坂本ら? および河西ら帛は分化癌の基本的特徵である乳 頭状構造, 濾胞状構造が不明瞭であり, かつ未 分化癌ほどの細胞異型を示さないものを低分化 癌と定義し, 広義の分化癌を高分化癌と低分化 癌に分類した。そして, 低分化癌は臨床的にも 未分化癌ほどの悪性度は示さないが高分化癌に 比し明らかに予後が悪いことを指摘し, 明らか な T3症例では気管壁の合併切除が, N3症例で は radical neck dissection が望ましいと述べて いる ${ }^{8)}$

自験例では，喉頭・気管に浸潤した分化癌 9 
例中 3 例 $(33.3 \%)$ が低分化癌であり，非浸潤 例34例中 6 例 $(17.6 \%$ ）に比し低分化癌の頻度 が高かった。また，津森ら ${ }^{6)}$ も, 気道浸潤例の低 分化癌の頻度は, 分化癌 11 例中 6 例 $(54.5 \%)$ で, 非浸潤例70例中の 8 例 (11.4\%) と比べ高 率であったと報告しており，自験例と同様の傾 向であった。喉頭・気管浸潤例では低分化癌の 比率が高いものと推測された。

術前の腫瘍の浸潤範囲の検索には, 喉頭・気 管の断層写真, CT が有用であった。とくに CT は, 図 1 に示すごとく喉頭・気管への腫瘍の浸 潤程度のみではなく，食道，大血管などの周囲 組織と腫瘍の関係をみるのに有用であった。中 尾ら ${ }^{10)}$ ，鈴木ら ${ }^{11)}$ も CT の有用性について報告 しており，鈴木らは総頸動脈への浸潤は腫瘍に よりその全周が覆われるか, または総頸動脈の 変形が認められた場合に浸潤があると診断で き, 食道への浸潤は，食道と腫瘍との間の脂肪 層の消失が矢状方向 $3 \mathrm{~cm}$ 以上の場合に強く疑 われると述べている。

また，リンパ節転移，とくに触診が困難な傍 気管, 縌隔リンパ節への転移の検索には山口 $ら^{12)}$ 報告のように ${ }^{201} \mathrm{Tl}$ シンチグラムが有用 と思われた（図 2 )。

治療は，4例に喉頭全摘， 7 例に気管合併切 除を施行した。気管の再建は, 局所の有茎皮弁 と DP 皮弁にて二次的に行なった。自験例中に は，気管の管状切除を要した症例はなかった。 海老原ら ${ }^{5}$ ，気管の周 $1 / 2$ 以下 4 輪以下ならば 皮弁による二次的再建は容易でなんの問題もな いと述べている。また，石原らきは，気管外科の 進歩により, 8 気管輪程度の切除範囲であれば, 端々吻合が可能であると述べている。

予後は, 手術施行した11例中 8 例が生存中で あり，死亡した 3 例でも頸部リンパ節再発をき たした例が 1 例あるのみで他に局所再発を認め た例はなかった。また，気管形成も局所皮弁や DP 皮弁にて安全かつ確実に行なうことがで き, われわれ，喉頭・気管へ浸潤した甲状腺 癌症例に対しても積極的に手術を施行すべきと 考えている。

\section{IV．まとめ}

1. 喉頭・気管へ浸潤した甲状腺癌症例12例

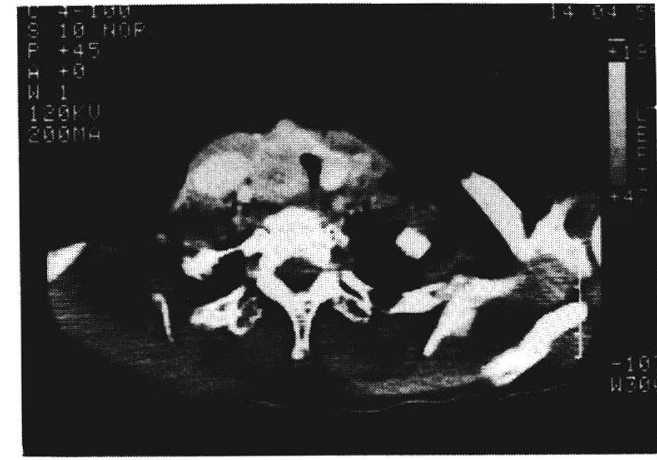

図 1 CT像

腫場の気管内浸潤が明らかであり，周 囲組織との関係も明確である。

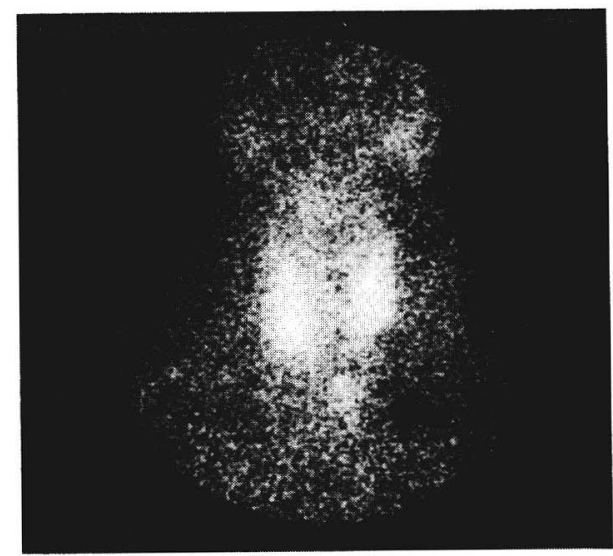

図 $2201 \mathrm{Tl}$ シンチグラム

傍気管リンパ節への集積を認める (矢印)。

の検討を行なった。

2 . 性差は, 男性 1 例, 女性11例であり, 年 齢は，48歳〜75歳で平均59歳であった。

3. 自覚症状は, 嗄声, 呼吸困難が多かった。

4. 手術術式は, 喉頭全摘 4 例, 気管開空 7 例, 手術不能 1 例であった。

5. 病理組織学的には, 乳頭癌 8 例, 濾胞癌 1 例, 未分化癌 2 例, 扁平上皮癌 1 例であり, 分化癌 9 例中 3 例 (33.3\%) が低分化癌であっ た。

6. 腫瘍の浸潤範囲の診断には, 喉頭・気管 断層写真, CT が有用であり,リンパ節転移に対 しては ${ }^{201} \mathrm{~T} 1$ シンチグラムが有用であった。

7. 手術施行した11例中, リンパ節再発をき たした症例が 1 例のみであり，喉頭・気管に浸 
日気食会報，38（1），1987

潤した甲状腺癌症例に対しては，積極的に手術 施行すべきと思われた。

本論文の要旨は, 第35回日本気管食道科学会総会 にてロ演した。

\section{引用文献}

1) 桜井一生・他：甲状腺腫瘍の臨床的検討, 耳鼻 臨床, $76: 287-293,1983$.

2) 中村昭郎・他：甲状腺癌の実態および臨床的考 察, 耳鼻臨床, $68: 711-721,1975$.

3）佐藤武男・他：耳鼻咽喉科における甲状腺癌の 実態と治療，耳鼻臨床，64：514-522, 1971.

4 ) 佐藤文彦・他：甲状腺癌の臨床的考察, 日耳鼻, $74: 1482-1495,1971$.

5 ）海老原敏・他：甲状腺癌，ホルモンと臨床, 29 ： 413-416, 1981.

6 ）津森孝生・他：気道浸潤甲状腺癌の臨床病理学 的検討, 日外会誌, $86: 404-410,1985$.
7）坂本穆彦·他：甲状腺低分化癌, 癌の臨床, 26 ： 131-135, 1980.

8 ）河西信勝 - 他：甲状腺低分化癌の臨床，癌の臨 床, $27: 20-25,1981$.

9 ) 石原恒夫・他：気管・喉頭浸潤癌に対する手術, 内分泌外科, $2: 281-286,1985$.

10）中尾量保・他：喉頭・気管に浸潤した甲状腺癌 に対する根治手術，日外会誌，83：1369-1376, 1982.

11）鈴木恵子・他：甲状腺癌における CT の意義, 日本医放会誌，45：600-605, 1985.

12）山口晃弘・他： ${ }^{201} \mathrm{Tl}$ chloride scintigraphy に上 る甲状腺癌再発の診断, 外科, $43: 1338-1348$, 1981.

別刷請求：テ470-11 豊明市沓掛町田楽ケ䇠1-98 藤田学園保健衛生大学医学部耳鼻咽喉科 桜井一生

（投稿受付 1986 年 5 月 7 日） 